\title{
PENERAPAN MODEL SIKLUS BELAJAR 7E UNTUK MENINGKATKAN AKTIVITAS DAN HASIL BELAJAR IPA SISWA KELAS VIIID SMP N 2 NUSA PENIDA SEMESTER GANJIL TAHUN PELAJARAN 2019/2020
}

\section{Putu Eka Rusmayani}

SMP Negeri 2 Nusa Penida

Email: ekarusmayani11@gmail.com

\section{Info Artikel}

Sejarah Artikel:

Diserahkan: 1 Mei 2021

Direvisi: 1 Juli 2021

Disetujui: 27 Juli 2021

Keywords:

\section{Abstract}

This research is a classroom action research (PTK). This study aims to 1) increase the activity of class VIIID students of SMP Negeri 2 Nusa Penida in science learning, 2) to improve learning outcomes of class VIIID students of SMP Negeri 2 Nusa Penida in learning the subject of learning (1) Structure and Function of Plants, (2) ) Digestive System in Humans, (3) Additives and Addictive Substances, (4) Circulatory System in Humans. The subjects of this study were class VIIID students of SMP Negeri 2 Nusa Penida in the 2019/2020 academic year in the odd semester, totaling 24 students, consisting of 12 girls and 14 boys. This research was carried out every cycle in two cycles, where each cycle was carried out through 4 stages, namely: 1) research planning, 2) action implementation, 3) observation / evaluation, and 4) reflection. Sources of data for student activities can be obtained from direct observation sheets at the time of learning each cycle. Meanwhile, the data on students' science learning outcomes are students' answers to the science learning outcomes test given at the end of the cycle. Student activity data for each cycle was analyzed using a score of $0-1$, with the criteria for student activity using the benchmark reference assessment rubric. Meanwhile, the data on students' science learning outcomes were analyzed using a rubric for conceptual standards using a 0-1 rating scale for objective questions, while the description questions scored 1-8. The results of this study indicate that: (1) there is an increase in student activity, from 67.73 moderate in the first cycle to 79.675 .38 in the good category in the second cycle. (2) there is an increase in student learning outcomes from the first cycle of 65.50 to 71.54 in the second cycle. Based on the findings above, it is suggested that: findings about the effective application of the 7E learning cycle model as an alternative in the science learning process. 


\section{PENDAHULUAN}

Tantangan dalam pembelajaran adalah menciptakan pengalaman yang melibatkan siswa, mendukung mereka berpikir, memahami, menjelaskan, dan memecahkan permasalahan ilmiah (Akinbobola \& Afalabi 2010). Berbagai inovasi pendidikan telah dilakukan oleh pemerintah maupun pihak swasta untuk meningkatkan mutu pendidikan di Indonesia. Inovasi sudah dilakukan pada jenjang pendidikan dasar dan menengah sampai pendidikan tinggi. Pemerintah telah menerapkan Kurikulum Tingkat Satuan Pendidikan (KTSP) sejak tahun 2005 hingga dilaksakanannya Kurikulum 2013 (K-13).

Kurikulum 2013 dirancang dan diimplementasikan untuk menghasilkan lulusan yang kompeten memiliki pengetahuan, keterampilan, sikap, dan nilainilai dasar yang direfleksikan dalam berpikir dan berbuat. Pembelajaran kontruktivis menekankan pengajaran yang berpusat pada pebelajar (Chowdhury \& College, 2006; Slavin, 2009). Dalam pembelajaran IPA, hendaknya peserta didik terlibat secara aktif untuk mengkonstruksi dan mengasimilasi pengetahuan melalui kegiatan inkuiri ilmiah untuk menumbuhkan kemampuan berpikir, bekerja dan bersikap ilmiah serta mengkomunikasikannya sebagai aspek penting kecakapan hidup. Belajar merupakan proses perubahan dan pembangunan pengetahuan baru (Sornsakda, et al., 2009). Belajar merupakan proses mengkonstruksi arti. Seseorang yang belajar berarti membentuk pengertian. Pembentukan arti tersebut dapat melalui asimilasi, akomodasi pengalaman atau bahan yang akan dipelajari dengan pengertian yang sudah dimiliki seseorang hingga berkembang. Untuk dapat membelajarkan peserta didik secara aktif, maka guru harus mampu menjadi seorang fasilitator atau mediator yang inovatif sehingga mampu menyediakan wahana bagi peserta didik untuk mempelajari konsep IPA, serta prospek pengembangan lebih lanjut dalam menerapkannya di dalam kehidupan seharihari.

Pemahaman konsep yang baik erat kaitannya dengan hasil belajar siswa. Penelitian ini berkaitan langsung dengan proses pembelajaran khususnya bidang sains (IPA) di SMP Negeri 2 Nusa Penida. Sampai saat ini pemahaman konsep siswa masih rendah. Berdasarkan penilaian hasil belajar siswa dalam mata pelajaran IPA KELAS VIII pada KD $3.1 ; 3.2$; dan 3.3 semester ganjil Tahun pelajaran 2019/2020 rata-rata nilai ulangan harian 1 masih belum memenuhi syarat kriteria ketuntasan minimal IPA kelas VIII yaitu 76. Rata-rata nilai hasil belajar siswa kelas VIII pada VIII pada KD 3.1; 3.2; dan 3.3, pada tahun ajaran 2019/2020 yaitu 59,95 dengan ketuntasan 48,89\%. Dari kelima kelas VIII, kelas VIIID SMP N 2 Nusa Penida memiliki nilai yang terendah dibandingkan kelas lainya. Berdasarkan hasil observasi diperoleh ratarata nilai ulangan pada semester 1 pada pra siklus, pada tahun ajaran 2019/2020 untuk kelas VIIID sebesar 51,28 dengan ketuntasan 38,46\%.

Berdasarkan pengamatan hasil prasiklus, rendahnya hasil belajar IPA siswa disebabkan oleh beberapa faktor, yaitu : (1) kemasan pembelajaran masih menitikberatkan pada kemampuan hafalan, memecahkan masalah lama, dan kurang memperhatikan pemahaman konsep siswa, (2) guru masih menggunakan paradigma "teaching by telling approach" dengan asumsi pengetahuan dapat dipindahkan dari guru ke siswa, (3) konsep IPA yang dibelajarkan dianggap sulit oleh peserta didik, (4) kurangnya pengkaitan antara konsep IPA yang dibelajarkan dengan masalah nyata, (5) kurangnya kegiatan praktikum dalam pembelajaran IPA sehingga aktivitas belajar rendah dan masih berpusat pada guru, dan (6) kinerja ilmiah yang menjadi tuntutan KTSP dalam penilaian proses pembelajaran belum dilakukan secara optimal yang menyebabkan hasil belajar siswa rendah. 
Rendahnya aktivitas dan hasil belajar siswa perlu mendapatkan perhatian serius karena nantinya akan berdampak pada mutu pendidikan siswa. Berdasarkan permasalahan di atas, perlu diterapkan strategi pembelajaran yang inovatif agar terjadi kegiatan pembelajaran yang berpusat pada peserta didik yang dapat meningkatkan hasil belajar dan aktivitas siswa. Salah satu produk yang dapat dikembangkan guru dalam teknologi pembelajaran adalah mengembangkan model pembelajaran untuk membangun keterampilan berpikir siswa salah satunya adalah metode penemuan. Pembelajaran dengan metode penemuan adalah belajar yang berkesinambungan. Hal ini disebut siklus belajar. Siklus belajar (learning cycle) merupakan suatu model belajar yang berpusat pada pebelajar (Sornsakda, et al., 2009; Polyiem, et al., 2011). Model siklus belajar 7E merupakan salah satu model belajar yang berlandaskan konstruktivis. Pembelajaran ini berfokus pada penyelidikan konsep-konsep dan menemukan hubungannya melalui pengalaman langsung dan menjadikannya jaringan konseptual yang terpadu. Siklus belajar 7E menurut Eisenkraft (2003) terdiri atas tujuh fase: yaitu elecition phase, engagement phase, exploration phase, explanation phase, elaboration phase, evaluation phase, dan extentioan phase.

Beberapa penelitian terdahulu yang memiliki kemiripan dengan penelitian ini antara lain penelitian yang dilakukan oleh, Susilawati, dkk (2014), Adilah dan Budiharti (2015), Sumiyati, dkk (2016), Haryanto, dkk (2016), dan Maulina, dkk (2018). Hasil penelitian yang dilakukan Susilawati, dkk (2014) menunjukkan adanya perbedaan pemahaman pemahaman konsep siswa yang diajar menggunakan model pembelajaran siklus 7E dengan siswa yang diajar menggunakan model pembelajaran langsung. Hasil ini ditunjukkan oleh nilai Fhitung $(6,237)$ lebih besar dari Ftabel $(3,98)$, dan rata-rata gain score pemahaman konsep siswa yang dibelajarkan dengan model pembelajaran 7E $(\mathrm{X}=0,41)$ lebih besar dari rata-rata gain score kelompok siswa yang dibelajarkan dengan model pembelajaran langsung $(X=0,31)$.

Riset Adilah dan Budiharti (2015) menemukan bahwa model pembelajaran siklus 7E cocok diterapkan dalam pembelajaran IPA. Model pembelajaran siklus 7E yang memiliki tujuh siklus dianggap memiliki korespondensi dengan hakikat IPA yang meliputi unsur sikap, proses, produk, dan aplikasi. Model ini juga dapat menumbuhkan keterlibatan siswa secara aktif dalam pembelajaran IPA.

Penelitian yang dilakukan Sumiyati, dkk (2016) menemukan penggunaan model siklus 7E mampu meningkatkan hasil belajar siswa pada materi proses daur air. Penelitian dilakukan dalam 3 siklus pembelajaran. Masing-masing siklus menunjukkan adanya peningkatan hasil belajar siswa. Kondisi awal ditemukan hanya 5 siswa yang tuntas dalam pembelajaran materi proses daur ulang air. Setelah materi diajarkan menggunakan model siklus 7E didapatkan 11 siswa tuntas pada siklus I, 17 siswa tuntas pada siklus II, dan 20 siswa tuntas pada siklus III. Aktivitas siswa pada proses pembelajaran menggunakan model siklus 7E mengalami peningkatan sangat signifikan. Siklus I aktifitas siswa masih pada angka $62 \%$, sementara pada siklu II meningkat menjadi $87 \%$, dan siklus III 92\%. Sementara penelitian Haryanto, dkk (2016) menemukan aktivitas belajar siswa pada kelas yang diajar menggunakan model siklus 7E lebih baik dibanding kelas yang diajar menggunakan model konvnsional. Kelas yang menerapkan model siklus $7 \mathrm{E}$ rata-rata aktivitas siwa sebesar 70,95\%, sedangkan kelas dengan model konvensional rata-rata aktivitas belajar siswa pada angka $61,38 \%$.

Maulina, dkk (2018) melalui risetnya menemukan terdapat peningkatan hasil belajar siswa setelah guru menggunakan model siklus 7E. Siklus I hasil belajar siswa mengalami peningkatan dengan nilai ratarata 78,4 dan ketuntasan klasikal sebanyak 
79\%. Siklus II nilai rata-rata sebesar 83,7 dengan ketuntasan klasikal sebesar $84 \%$.

Berdasarkan latar belakang masalah yang dipaparkan, maka dalam penelitian ini mengkaji dua hal yaitu sebagai berikut. Apakah pembelajaran model siklus belajar 7E dapat meningkatkan aktivitas siswa kelas VIIID SMP Negeri 2 Nusa Penida dalam pembelajaran IPA dan apakah pembelajaran model siklus belajar 7E dapat meningkatkan hasil belajar IPA siswa kelas VIIID SMP Negeri 2 Nusa Penida.

\section{METODE PENELITIAN}

Penelitian yang dilakukan adalah penelitian tindakan kelas yang dirancang dalam dua siklus. Setiap siklus dilaksanakan melalui 4 tahapan, yaitu: 1) perencanaan penelitian, 2) pelaksanaan tindakan, 3) observasi/evaluasi, dan 4) refleksin. Penelitian ini menggunakan desain penelitian yang dimodifikasi dari Kemmis dan Mc Taggrat (dalam Soejono, 1998 Subyek penelitian tindakan adalah semua peserta didik kelas VIIID SMP Negeri 2 Nusa Penida Semester I tahun pelajaran 2019/2020 yang berjumlah 26 orang, terdiri atas 12 putri dan 14 putra. Pemilihan subyek ini didasarkan pada rerata ulangan harian I pada kompetensi dasar sebelumnya tidak mencapai ketuntasan klasikal. Sedangkan obyek penelitian adalah hasil belajar IPA dan aktivitas siswa dalam pembelajaran IPA untuk KD 3.4; 3.5; 3.6; 3.7
Model belajar yang digunakan adalah Siklus belajar 7E terdiri atas tujuh fase: yaitu elecition phase, engagement phase, exploration phase, explanation phase, elaboration phase, evaluation phase, dan extentioan phase.

Sumber data untuk aktivitas siswa di dapat dari lembar observasi langsung pada saat pembelajaran tiap siklus. Sedangkan data hasil belajar siswa adalah jawaban siswa dari tes hasil belajar yang diberikan pada akhir siklus. Instrumen pengumpul data yang digunakan berupa lembar observasi dan tes hasil belajar. yang disusun dan dikembangkan sendiri oleh penulis. Instrumen penilaian aktivitas belajar terdiri dari empat indikator, yaitu: (1) kerja sama dalam kelompok belajar, (2) peran dalam kelompok belajar, (3) perhatian terhadap kegiatan pembelajaran, dan (4) inisiatif dalam pembelajaran. Perilaku atau sikap peserta didik yang diobservasi diberikan skor. Data tentang aktivitas siswa dianalis dengan cara penilaian setiap siswa diberikan penilaian 1 untuk yang memenuhi/sesuai dengan indikator sedangkan yang tidak memenuhi indikator diberikan skor nol, selanjutnya skor masing-masing siswa dicari melalui jumlah skor yang didapat siswa dibagi dengan julah skor maksimal yaitu 20 dikalikan dengan 100, selanjutnya dikonversi kedalan pedoman konversi pedoman acuan patokan sesuai Tabel 1.

Tabel 1. Pedoman Konversi PAP Skala Lima

\begin{tabular}{cc}
\hline Tingkat Penguasaan & Kualifikasi \\
\hline $85,0-100,0$ & Sangat Baik \\
\hline $75,0-84,9$ & Baik \\
\hline $55,0-79,9$ & Sedang \\
\hline $40,00-54,9$ & Kurang \\
\hline $0,0-39,9$ & Sangat Kurang \\
\hline
\end{tabular}

Untuk memperoleh data hasil belajar siswa IPA maka digunakan instrumen penilaian hasil belajar berbentuk obyektif sebanyak 15 (lima belas) item. Setiap item yang dijawab benar diberikan skor 1 dan item yang dijawab salah diberikan skor 0. Dan dan 5 (lima) soal uraian dengan skala 0-4 Selanjutnya skor yang diperoleh peserta didik dikonversikan dalam skala seratus seperti halnya mengkonversikan penilaian sikap di atas.

Ketuntasan aspek kognitif peserta didik ditentukan dengan menggunakan daya serap siswa/peserta didik (DSS) dan ketuntasan klasikal (KK). Ketuntasan siswa ditentukan berdasarkan Kriteria Ketuntasan Minimal (KKM) $\geq 67$ dan Ketuntasan klasikal atau $\mathrm{KK} \geq 67 \%$. Indikator keberhasilan kinerja dalam penelitian ditetapkan sebagai berikut: (1) aktivitas siswa dikatakan berhasil jika kualifikasinya berkatagori baik atau dengan nilai paling rendah 75. (2) hasil belajar siswa dikatakan berhasil jika nilai ratarata yang diperoleh siswa lebih besar dari KKM yaitu 67. Keseluruhan data hasil penelitian di analisis secara deskriptif menentukan tingkat aktivitas dan hasil belajar siswa. 


\section{HASIL DAN PEMBAHASAN Siklus I}

Siklus I dilaksanakan dalam tujuh kali pertemuan. Enam pertemuan untuk pembelajaran dan 1 kali untuk melaksanakan tes dengan menggunakan tiga rencana pembelajaran. Masing-masing pertemuan menggunakan RPP dan LKS kontruksi dalam pembelajaran. Materi yang dibahas pada siklus I meliputi: struktur dan fungsi tumbuhan; dan sistem pencernaan makanan.

Secara garis besar, deskripsi pelaksanaan kegiatan pembelajaran dengan menerapkan model siklus belajar sebagai berikut.

Pada pertemuan pertama, proses pembelajaran dimulai dengan kegiatan pendahuluan (Tahap election) yang berlangsung sepuluh menit. Rangkaian kegiatan pendahuluan terdiri dari: mengabsen siswa, membacakan kompetensi dasar dan membacakan indikator hasil belajar memerikan apersepsi, menyampaikan indikator pembelajaran, manfaat pembelajaran. Tahap engagemen: Guru mengajukan pertanyaan untuk mengetahui pengetahuan awal siswa, memotivasi siswa dalam mengekspresikan pengetahuannya, "Bagaimana padi dapat menghasilkan beras? Di manakah proses tersebut berlangsung? Bagian manakah dari tumbuhan yang berperan untuk proses tersebut?

Setelah mendapatkan jawaban yang beragam dari siswa, guru kemudian mengantarkan masalah tersebut pada materi yang akan dibahas. Guru mensosialisasikan pembelajaran dengan menerapkan model siklus belajar dan menyampaikan sistem penilaian yang akan dilaksanakan selama proses pembelajaran. Guru membacakan anggota masing-masing kelompok. Kegiatan dilanjutkan dengan kegiatan inti (60 menit).

Penyelidikan nyajikan fenomena yang berkaitan dengan konsep organ tumbuhan yang akan dipelajari.Siswa bekerja sama dengan anggota kelompok untuk menjelaskan fenomena yang disajikan, berdasarkan pengetahuan awalnya dengan menyampaikan sejumlah hipotesis (Tahap engagement ). Guru membagikan LKS dan siswa melaksanakan (Tahap (explore). Hasil eksperimen dianalisis oleh siswa untuk dapat menjawab hipotesis, dan menuangkannya dalam bentuk laporan (Tahap explanation). Guru membimbing siswa memahami konsepkonsep yang berkaitan dengan fenomena yang disajikan secara jelas dan sederhana. Siswa mengelaborasi pengetahuan yang sudah di bangun dengan pengetahuan awalnya (Tahap elaborasi). Kegiatan diakhiri dengan penutup selama 10 menit. Guru mengevaluasi sejauh mana pemahaman konsep siswa dan kemampuan pemecahan masalah yang dimiliki siswa (Tahap evaluation). Siswa mengaplikasikan pemahaman konsep yang dimiliki dengan menyebutkan contoh lain yang berkaitan dengan kehidupan sehari-hari, atau menyelidiki fenomena lain yang berkaitan dengan konsep yang telah diperkenalkan (Tahap extension). Untuk pertemuan kedua sampai ke enam, hampir sama dengan pertemuan pertama hanya materi yang dibelajarkan berbeda. Pada pertemuan kedua dibahas struktur dan fungsi daun, bunga, buah dan biji, Pada pertemuan ketiga dibahas jaringan pada tumbuhan. Pada pertemuan keempat bahan dan zat makanaan. Pada pertemuan kelima dibahas organ pencernaan makanan. Pada pertemuan keenam dibahas gangguan pada sistem pencernaan makanan.

Pelaksanaan tes hasil belajar untuk siklus I dilaksanakan pada pertemuan ke ketujuh. Tes hasil belajar pada siklus I mencakup materi pada siklus I. Pengukuran aktivitas belajar siswa dilaksanakan setiap pertemuan pada tiap tahapan siklus belajar 7E Kegiatan berlangsung lancar dan tidak ada yang mencontek.

Data hasil penelitian pada siklus I memuat tentang aktivitas peserta didik dalam pembelajaran IPA dan hasil belajar atau penguasaan konsep IPA. Rekapitulasi aktivitas siswa pada siklus I disajikan dalam Tabel 2.

Tabel 2. Rekapitulasi Aktivitas Siswa pada Siklus I

\begin{tabular}{llll}
\hline No & Aktivitas & Jumlah & Persentase \\
\hline 1 & Sangat baik & 5 & $19,23 \%$ \\
\hline 2 & Baik & 4 & $15,38 \%$ \\
\hline 3 & Sedang & 13 & $46,15 \%$ \\
\hline 4 & Kurang & 4 & $15,38 \%$ \\
\hline 5 & Jumlah Nilai siswa & 26 & \\
\hline 6 & Rata-rata & 67,73 & \\
\hline
\end{tabular}




\begin{tabular}{lll}
\hline 7 & Standar Deviasi & 13,73
\end{tabular}

Berdasarkan analisis data aktivitas siswa pada siklus I. diperoleh nlai aktivitas peserta didik terhadap pembelajaran IPA pada siklus I sebagai berikut: nilai minimum 45, nilai maksimum 90, rata-rata 67,73 dengan kategori akivitas kurang terhadap pembelajaran IPA $15,38 \%$ dengan $\mathrm{SD}=$ 13,73. Nilai aktivitas yang diperoleh belum mencapai indikator keberhasilan kinerja penelitian yang berkategori baik.

Untuk nilai hasil belajar siklus I diperoleh nilai minimal 30 dan nilai maksimal 90, dengan rata-rata 65,50 dengn ketuntasan klasikal $50 \%$. Nilai hasil belajar pada siklus I belum mencapai kriteria ketuntasan yang telah ditetapkan sebelumnya yaitu 67 .

Tabel 3. Rekapitulasi Data Hasil Belajar Siswa pada Siklus 1

\begin{tabular}{|c|c|c|c|}
\hline No & 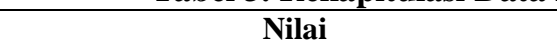 & Jumlah & Persentase \\
\hline 1 & Nilai Minimal & 30 & \\
\hline 2 & Nilai Maksimal & 90 & \\
\hline 3 & Jumlah Siswa Tuntas (diatas 67) & 13 & $50 \%$ \\
\hline 4 & Jumlah Siswa Belum Tuntas (dibawah 67) & 13 & $50 \%$ \\
\hline 5 & Jumlah Nilai Siswa & 1703 & \\
\hline 6 & Rata-rata & 65,50 & \\
\hline 7 & Standar Deviasi & 15 & \\
\hline
\end{tabular}

Refleksi pada siklus I didasarkan hasil observasi dan evaluasi proses pembelajaran pada siklus I. Selama proses pembelajaran secara umum berjalan lancar, namun ada beberapa kendala yang dihadapi dalam proses belajar.

1. Saat meminta siswa menuju kelompoknya masing-masing, ada siswa yang bercanda yang menyebabkan kelas menjadi gaduh.

2. Saat mengerjakan tugas kelompok, masih ada siswa yang tidak ikut bekerja dalam kelompoknya, dan hanya siswa yang berkemampuan lebih saja yang mengerjakannya sendiri.

3. Saat diskusi kelas, hanya sebagian kecil siswa yang memberi tanggapan, sedangkan siswa lain kurang semangat.

4. Berdasarkan kendala-kendala yang dihadapi siklus I, maka diambil langkah dalam proses pembelajaran sebagai berikut.

5. Memberi peringatan kepada siswa agar tidak membuat gaduh dalam pembelajaran

6. Memberi bimbingan dan memotivasi agar anggota kelompok saling bekerja sama

7. Merancang LKS yang digunakan agar lebih dapat dipahami siswa

8. Memberikan penghargaan bagi siswa yang memberikan tanggapan pada saat diskusi dan mendapatkan nilai terbaik.

\section{Siklus II}

Siklus II dilaksanakan dalam 2 rencana pembelajaran untuk enam kali pertemuan. Materi yang dibahas pada siklus II meliputi: zat aditif, pengaruh zat aditif bagi kesehatan, penyalahgunaan zat aditif, organ peredaran darah, sistem peredaran darah pada manusia. Secara garis besar, deskripsi pelaksanaan kegiatan pembelajaran dengan siklus belajar 7E adalah sebagai berikut.

Pada pertemuan kedelapan, proses pembelajarn dimulai dengan kegiatan pendahuluan yang berlangsung kurang dari 10 menit. Pada kegiatan pendahuluan terdiri atas: Pada pertemuan pertama, proses pembelajaran dimulai dengan kegiatan pendahuluan (Tahap eleciion) yang berlangsung sepuluh menit menit. Rangkaian kegiatan pendahuluan terdiri dari: mengabsen siswa, membacakan kompetensi dasar dan membacakan indikator hasil belajar memberikan apersepsi, menyampaikan indikator pembelajaran, manfaat pembelajaran, mengajukan pertanyaan untuk mengetahui pengetahuan awal siswa, memotivasi siswa dalam mengekspresikan pengetahuannya. " Ketika pulang sekolah, apakah kamu sering bertemu dengan penjual makanan atau minuman? Bagaimana pendapatmu tentang tampilan dan rasa makanan serta minuman tersebut? Agar memiliki warna yang menarik dan memiliki rasa yang lezat, 
penjual biasanya menambahkan zat tertentu dalam makanan dan minuman agar menarik. Bagaimana pendapatmu tentang makanan dan minuman tersebut yang berwarna-warni tersebut? Apakah makanan dan minuman tersebut nampak menarik? Apakah makanan sehat?"

Kegiatan dilanjutkan dengan kegiatan inti (60 menit). Guru mengidentifikasi dan menyajikan fenomena yang berkaitan dengan konsep yang akan dipelajari. Siswa bekerja sama dengan anggota kelompok untuk menjelaskan fenomena yang disajikan, berdasarkan pengetahuan awalnya dengan menyampaikan sejumlah hipotesis (Tahap engagement). Guru membagikan LKS dan siswa melaksanakan eksperimen (Tahap explor). Hasil eksperimen dianalisis oleh siswa untuk dapat menjawab hipotesis, dan menuangkannya dalam bentuk laporan (Tahap explanation). Guru membimbing siswa memahami konsep-konsep yang berkaitan dengan fenomena yang disajikan secara jelas dan sederhana. Siswa mengelaborasi pengetahuan yang sudah di bangun dengan pengetahuan awalnya (Tahap elaborasi). Kegiatan diakhiri dengan penutup selama 10 menit. Guru mengevaluasi sejauh mana pemahaman konsep siswa dan kemampuan pemecahan masalah yang dimiliki siswa (Tahap evaluation). Siswa mengaplikasikan pemahaman konsep yang dimiliki dengan menyebutkan contoh lain yang berkaitan dengan kehidupan sehari-hari, atau menyelidiki fenomena lain yang berkaitan dengan konsep yang telah diperkenalkan (Tahap extension). Untuk pertemuan sembilan sampai 11, hampir sama dengan pertemuan kedelapan materi yang dibelajarkan berbeda, pengaruh zat aditif bagi kesehatan, penyalahgunaan zat aditif, organ peredaran darah, sistem peredaran darah pada manusia.

Rekapitulasi data nilai aktvitas siswa pada siklus II disajikan dalam Tabel 4 dan rekapitulasi data hasil belajar siswa untuk siklus II disajikan dalam Tabel 5.

Tabel 4. Data Rekapitulasi Aktivitas Siswa pada Siklus II

\begin{tabular}{clcc}
\hline No & Indikator Aktivitas & Jumlah & Persentase \\
1 & Sangat baik & 7 & $26,92 \%$ \\
2 & Baik & 6 & $23,08 \%$ \\
3 & Sedang & 12 & $41,15 \%$ \\
4 & Kurang & 1 & $3,85 \%$ \\
5 & Jumlah Nilai siswa & 1960 & \\
6 & Rata-rata & 75,38 & \\
7 & Standar Deviasi & 13,71 & \\
\hline
\end{tabular}

Berdasarkan analisis data aktivitas siswa pada siklus II. diperoleh nilai sikap peserta didik terhadap pembelajaran IPA pada siklus II sebagai berikut: nilai minimum 50, nilai maksimum 95, rata-rata 75,38 dengan kategori sikap sedang terhadap pembelajaran IPA 41,15 \% dengan SD $=13,71$. Nilai ini sudah mencapai indikator keberhasilan kinerja penelitian kategori aktivitas siswa selama penelitian yaitu 75 dengan kategori baik.

\section{Tabel 5. Rekapitulasi Data Hasil Belajar Siswa pada Siklus II}

\begin{tabular}{clcc}
\hline No & Nilai & Jumlah & Persentase \\
1 & Nilai Minimal & 30 & \\
2 & Nilai Maksimal & 88 & \\
3 & Jumlah Siswa Tuntas (diatas 67) & 18 & $69,23 \%$ \\
4 & Jumlah Siswa Belum Tuntas (dibawah 67) & 10 & $38,46 \%$ \\
5 & Jumlah Nilai Siswa & 1876 & \\
6 & Rata-rata & 71,54 & \\
7 & Standar Deviasi & 16 & \\
\hline
\end{tabular}


Untuk nilai hasil belajar IPA siklus II sebagai berikut: nilai minimum 30 nilai maksimum 88, rata-rata 71,54 dengan ketuntasan klasikal (KK) 69,23\%. Nilai yang diperoleh sudah mencapai indikator keberhasilan kinerja penelitian (lebih besar dari KKM 67).
Data hasil rekapitulasi nilai rata-rata aktivitas belajar dan nilai rata-rata hasil belajar siswa masing-masing siklus tertera pada Tabel 6. Profil aktivitas belajar dan hasil belajar siswa tiap masing-masing siklus disajikan pada Gambar 1.

Tabel 6. Rekapitulasi Aktivitas dan Hasil Belajar Siswa Tiap Siklus

\begin{tabular}{llcc}
\hline No & \multicolumn{1}{c}{ Indikator } & Nilai Rata & Indikator Keberhasilan \\
1 & Hasil Belajar Siklus I & 65,50 & Belum Mencapai KK 67 \\
2 & Hasil Belajar Siklus II & 71,54 & Sudah Mencapai KK \\
3 & Aktivitas Siklus I & 67,73 & Kurang \\
4 & Aktivitas Siklus II & 75,38 & Baik \\
\hline
\end{tabular}

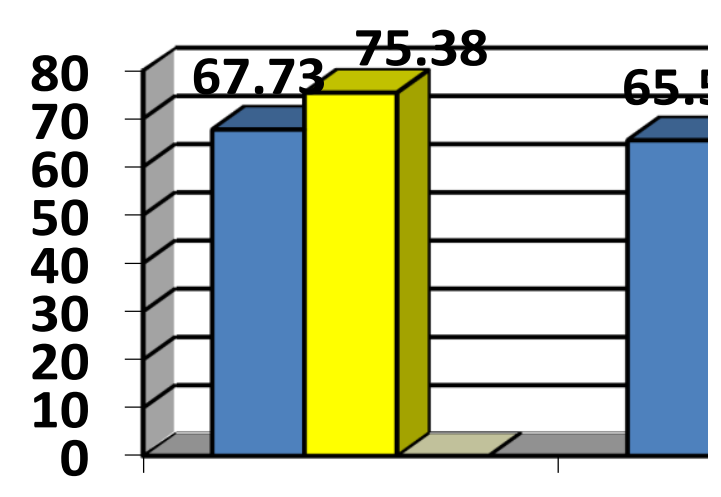

Gambar 1. Profil Sikap dan Hasil Belajar IPA Siswa Tiap Siklus

Berdasarkan hasil analisis data dari siklus I ke siklus II terjadi peningkatan secara signifikan, yaitu peningkatan aktivitas siswa selama pembelajaran sebesar $7,65 \%$ dan peningkatan hasil belajar sebesar $6,04 \%$.

\section{Pembahasan}

Berdasarkan analisis yang dilakukan, diperoleh hasil bahwa aktivitas siswa pada siklus pertama secara klasikal adalah 67,31 dengan katagori sedang, tetapi ada 4 siswa dengan aktivitas kurang atau perlu bimbingan Ini menunjukkan bahwa aktivitas perlu ditingkatkan lagi pada siklus berikutnya. Sedangkan pada siklus kedua aktivitas siswa sudah mencapai 75,38 dengan katagori baik dan masih ada 1 orang siswa yang memiliki aktivitas dengan katagori kurang 1 orang. Ini berarti ada peningkatan aktivitas dari siklus pertama. Dalam penelitian ini aktivitas yang sulit ditingkatkan adalah interaksi siswa dengan guru, hal ini karena siswa sudah terbiasa dengan pembelajaran konvensional yang hanya dengan metode ceramah saja.

Hasil analisis mengenai hasil belajar IPA siswa didapatkan hasil pada siklus pertama bahwa hasil rata-rata siswa adalah 65,50 Jika dibandingkan dengan KKM mata pelajaran IPA untuk kelas VIII, yaitu 67, memang lebih rendah dan juga kalau kita bandingkan dengan ulangan harian mereka sebelumnya pada mata pelajaran IPA jauh lebih tinggi, tetapi masih ada 15 siswa yang belum tuntas pada siklus pertama ini. Pada siklus kedua didapatkan hasil hasil belajar siswa yaitu rata-rata kelas 71,54 dengan 10 anak belum tuntas. Hal ini menunjukkan adanya peningkatan hasil belajar siswa dari siklus I ke siklus II.

Pada tiap tahapan siklus ke II guru lebih intensif menerapakan Model pembelajaran 7E. Siswa pun sudah mulai terbiasa dan menikmati tahapan pembelajaran dikelas dengan model ini. Para siswa menikmati pembelajaran secara langsung berinteraksi dengan alam. Pembelajaran ini berfokus pada penyelidikan konsep-konsep dan menemukan hubungannya melalui pengalaman langsung dan menjadikannya jaringan konseptual yang terpadu. Fase pertama adalah elecition phase yaitu memperoleh informasi, guru mengajukan pertanyaan untuk mengetahui pengetahuan awal siswa. Fase kedua adalah engagement phase adalah fase menarik perhatian, guru memotivasi siswa dalam mengekspresikan pengetahuan mereka, membuat siswa menjadi penasaran, ingin tahu, dan tertarik untuk belajar. Fase ketiga adalah exploration phase, siswa berinteraksi dengan lingkungan melalui kegiatan praktikum, mencatat data, membatasi variabel, merancang dan membuat grafik, menginterpretasi hasil, mengembangkan hipotesis dan membuat laporan. Fase keempat 
adalah explanation phase, yaitu siswa diperkenalkan model, hukum dan teori. Guru membimbing siswa dalam menjelaskan konsep dengan kalimat mereka sendiri, meminta bukti dan klarifikasi dari penjelasan mereka dan mengarahkan kegiatan diskusi. Fase kelima adalah elaboration phase, pengetahuan yang sudah dibangun oleh siswa dielaborasi dengan konsep awal siswa, dan menyimpulkan konsep baru dengan pemahaman sendiri. Fase keenam adalah evaluation phase, guru mengevalusi siswa dengan teknik yang bervariasi, untuk mengetahui sejauh mana pemahaman konsep siswa. Pada fase ketujuh yaitu extention phase, guru memotivasi siswa untuk menggunakan pengetahuan mereka sehingga mereka dapat menciptakan sesuatu yang baru. Pada tiap fase, akan dilatih kemampuan berpikir siswa, dan kemampuan pemecahan masalah yang disesuaikan dengan karakteristik materi. Guru melakukan perannya sebagai fasilitator secara maksimal dalam proses pembelajaran dan siswa pun pada siklus ke II ini lebih terbiasa melakukan pembelajaran dan antusian.

Temuan penelitian ini didukung oleh pembelajaran model siklus belajar 7E yang menyatakan bahwa:

Pertama, model siklus belajar 7E merupakan salah satu model belajar yang berlandaskan teori konstruktivis. dan teori pengembangan intelektual Piaget (Appamaraka, et al., 2009). Pembelajaran dengan siklus ini menyelidiki konsep-konsep dan hubungannya melalui pengalaman langsung ke dalam jaringan konseptual yang terpadu. Pada tiap fase, akan dilatih kemampuan berpikir siswa. Guru yang menerapkan siklus belajar 7E, dapat merancang pembelajaran yang mengaitkan pemahaman awal siswa dengan konteks, menyediakan situasi kondusif dalam belajar. Pengajaran dengan siklus belajar 7E dimulai dengan pengalaman langsung, mengamati suatu fenomena, bekerja dengan bahan dalam serangkaian kegiatan eksperimen dan diakhiri dengan penguasaan konsep secara ilmiah serta diikuti dengan penyuguhan konsep-konsep dan pengaplikasiaanya dalam kehidupan sehari-hari. Siswa belajar dengan aktif pada tiap tahapan fasenya. Pembelajaran konvensional merupakan sebuah praktik yang mekanistik dari pemberian informasi yang menggunakan paradigma behavioristik, menekankan pada resitasi konten, tanpa memberikan waktu yang cukup kepada siswa untuk merefleksi materi yang dipresentasikan, menghubungkannya dengan pengetahuan sebelumnya, atau mengaplikasikannya kepada situasi kehidupan nyata. Menurut Wenning (2010), penyelenggaraan pembelajaran konvensional lebih menekankan kepada tujuan pembelajaran berupa penambahan pengetahuan, sehingga belajar dilihat sebagai proses "meniru" dan siswa dituntut untuk dapat mengungkapkan kembali pengetahuan yang sudah dipelajari melalui kuis atau tes terstandar. Sedangkan peran siswa adalah menerima, menyimpan, dan melakukan aktivitas-aktivitas lain yang sesuai dengan informasi yang diberikan. Dalam proses pembelajaran keterampilan berpikir siswa jarang dilatih. Guru berasumsi bahwa keberhasilan program pembelajaran dilihat dari ketuntasannya menyampaikan seluruh materi yag ada dalam kurikulum.

Kedua, secara operasional empiris penelitian ini menggunakan LKS dengan materi yang sama. Perbedan LKS yang digunakan terletak pada strategi yang digunakan. Untuk LKS pada kelompok M7E menggunakan LKS yang sesuai dengan tahapan siklus belajar 7E. LKS ini menuntun siswa menemukan jawaban sendiri melalui serangkaiaan kegiatan seperti perumusn masalah, hipotesis, eksperimen. Sedangkan untuk kelompok pembelajaran konvensional menggunakan LKS yang berpola konvensional seperti LKS yang digunakan di sekolah, menerapkan pengetahuan secara linier. Pembelajaran dengan model siklus belajar 7E melatih siswa untuk bernalar, berpikir abstrak untuk memahami konsep, berpikir logis, berpikir dengan pemikiran teoretis formal berdasarkan proposisi-proposisi, membuat hipotesis, mengambil kesimpulan, mengaplikasikan pengetahuannya dan mengembangkan teori fisika.

Hasil penelitian ini relevan dengan penelitian-penelitian yang telah dilakukan sebelumnya. Polyiem, et al. (2011) menyelidiki "Learning achievement, science process skill, and moral reasoning of ninth grade students learned by 7E learning cycle and socioscientific issue-based learning". Tujuan penelitian adalah: (1) mengembangkan rencana pembelajaran dengan siklus belajar 7E berdasarkan isu sosial ilmiah, (2) menyelidiki keefektifan ke dua pendekatan, (3) membandingkan prestasi belajar, keterampilan proses, dan penalaran moral dari ke dua pendekatan pembelajaran. Hasil penelitiannya adalah kelompok siswa yang belajar dengan model siklus belajar 7E menunjukkan keunggulan yang signifikan dalam hasil belajar, keterampilan proses, dan kelompok siswa yang belajar dengan pendekatan yang berdasarkan isu sosial ilmiah menunjukkan keunggulan yang signifikan dalam pencapaian hasil belajar, keterampilan proses. Penelitian ini mengindikasikan 
keunggulan model siklus belajar 7E, dan penting diterapkannya model ini dalam pembelajaran untuk meningkatkan hasil belajar siswa.

Susilawati, et al. (2010: 324), meneliti pengaruh model siklus belajar hipotetikal deduktif 7E untuk meningkatkan kemampuan pemecahan masalah siswa. Ditemukan bahwa model siklus belajar hipotetikal deduktif 7E secara signifikan dapat lebih meningkatkan kemampuan pemecahan masalah siswa dibandingkan dengan model pembelajaran konvensional.

Rookhached, et al (2010) melakukan penelitian dengan judul "The Comparation of science education record in life and environment subject using the 7 steps learning cycle using multiple intelligences and metacognitive techniques with a teacher handbook learning that affecting to learning achievement, critical thinking and environmental preservation behavior of secondary school students, year 2 who have a different learning results". Tujuan penelitian yang dilakukan adalah mempelajari pendidikan sains di kehidupan sehari-hari dan lingkungan sekitar mengunakan tahap model siklus belajar 7E, multiple intlegensi, teknik metakognitif menggunakan modul guru dimana berpengaruh pada penilaian pembelajaran, berpikir kritis dan lingkungan belajar. Hasil penelitiannya adalah secara umum kelompok siswa yang belajar dengan siklus belajar 7E dengan multiple intlegensi, teknik metakognitif memiliki ratarata skor hasil belajar dan kemampuan berpikir kritis lebih dibanding siswa yang belajar dengan modul guru. Penelitian ini memaparkan model pembelajaran 7E, multiple intlegensi, teknik metakognitif yang dapat mengakomodasi kemampuan pemahaman konsep, dan berpikir kritis siswa. Keunggulan siklus belajar 7E yang berlandaskan pada pembelajaran kontruktivis yaitu pembelajaran perubahan konsep di tinjau dari teknik metakognitif dan kemampuan intelegensi.

Budprom, et al (2010) meneliti “ Effects of learninrg environmental education using the 5E-learning cycle with multiple intelligences and teacher's handbook approaches on learning achievement, basic science proses skills and critical thinking of grade 9 students". Tujuan penelitian adalah melidiki dan membandingkan pengaruh lingkungan pembelajaran menggunakan siklus belajar 5E dengan multiple intelegensi dan modul guru terhadap hasil belajar, keterampilan proses yang terintegrasi, dan berpikir kritis siswa. Hasil penelitian adalah: (1) kelompok siswa yang belajar dengan model siklus belajar $5 \mathrm{E}$ menunjukkan kelebihan hasil belajar, keterampilan proses yang terintegrasi, dan berpikir kritis dengan kelompok siswa yang belajar konvesnsional. (2) kelompok siswa yang belajar dengan modul guru menunjukkan kelebihan hasil belajar, keterampilan proses yang terintegrasi, dan berpikir kritis dengan kelompok siswa yang belajar konvesnsional. Akinbobola \& Afalabi (2010) dengan penelitiannya "Construktivist practices through quided discovery approach: The effect on students' cognitive achievement in Nigeria senior secondary school physics" melakukan penyelidikan terhadap pengaruh pendekatan pembelajaran (penemuan terbimbing, demontrasi dan ekpositori) terhadap penilaian kognitif dalam pembelajaran. Hasil penelitian menunjukkan pendekatan penemuan terbimbing paling efektif memfasilitasi kemampuan fisika siswa setelah pembelajaran menggunakan gambaran ilustrasi, kemudian diikuti dengan demontrasi, dan pembelajaran ekspositori.

Sornsakda, et al. (2009), melakukan penelitian "Effects of learning environmental education using the 7E-learning cycle with metacognitive techniques and teacher's handbook approaches on learning achievement, integrated science proses skills and critical thinking of mathayomsuksa 5 students with different learning achievement" dengan tujuan menyelidiki pengaruh penerapan siklus 7E dengan teknik metakognitif terhadap hasil belajar. Ditemukan bahwa secara umum kelompok siswa yang belajar dengan siklus belajar 7E dengan teknik metakognitive memiliki rata-rata skor hasil belajar diatas pada semua aspek keteramplan proses dan aspek berpikir kritis. Penelitian ini memaparkan model pembelajaran 7E dapat mengakomodasi keterampilan proses siswa, dan kemampuan berpikir kritis.

Tayraukham, et al. (2009), meneliti tentang "Effects of 7-E, KWL and conventional instruction on analytical thinking, learning achievement and attitudes toward chemistry learning. Penelitian ini menyelidiki pengaruh pengajaran 7E, KWL, dan konvensional terhadap kemampuan berpikir analisis, hasil belajar, dan sikap siswa. Hasil temuannya mengungkapkan siswa yang belajar dengan siklus 7E menunjukkan hasil yang lebih baik dari siswa yang belajar dengan metode KWL dan mengindikasikan hasil yang lebih baik dalam kemampuan analisis, dan sikap dengan pendekatan konvensional.

Kitjinda, et al. (2009), menyelidiki "Effects of environmental education learning 
by using the 7E-learning cycle with multiple intellegences and teacher's handbook approaches on learning achievement, critical thinking and integrated science proses skills of highh school (grade 10) students". Tujuan penelitian adalah menyelidiki pengaruh lingkungan belajar dengan menggunakan model siklus belajar 7E dengan intelegensi, kemampuan berpikir kritis dan keterampilan proses yang terintegrasi. Hasil temuannya mengungkap siswa yang belajar menggunakan model siklus belajar 7E dengan multiple intelegensi, menunjukkan peningkatan pada hasil belajarnya, kemampuan berpikir kritis, dan peningkatan keterampilan proses. Penelitian ini mengindikasikan pentingnya guru menerapkan model siklus belajar 7E dalam mengembangkan pemahaman konsep siswa.

\section{SIMPULAN}

Berdasarkan hasil pengujian hipotesis penelitian dan pembahasan yang telah diuraikan di atas, maka dalam penelitian dapat disimpulkan sebagai berikut: (1) Aktivitas siswa kelas VIIID SMP Negeri 2 Nusa Penida semester ganjil pada Pelajaran IPA tahun pelajatan 2019/2020 mengalami peningkatan. Hal ini dapat dilihat dari rata-rata aktivitas belajar IPA pada siklus I sebesar 67,73 (kategori sedang) mengalami peningkatan sebesar 7,65 pada siklus II menjadi 75,38 (berkategori baik). (2) Hasil Belajar IPA siswa kelas VIIID SMP Negeri 2 Nusa Penida semester ganjil pada Pelajaran IPA tahun pelajatan 2019/2020 mengalami peningkatan. Hal ini dapat dilihat dari rata-rata hasil belajar IPA pada siklus I sebesar 65,50 mengalami peningkatan sebesar 6,04 pada siklus II menjadi 71,54 .

\section{DAFTAR PUSTAKA}

Adilah, Nur Dina \& Budiharti, Rini. 2015. Model Learning Cycle 7E Dalam Pembelajaran IPA Terpadu. Prosiding Seminar Nasional Fisika dan Pendidikan Fisika (SNFPF) Ke-6.

Akinbobola, A. O., \& Afalabi, F. 2010. Construktivist practices through quided discovery approach: The effect on students' cognitive achievement in Nigeria senior secondary school physics. Journal of Physics and Chemistry Education. 2 (1): 16-25.

Appamaraka, S., Suksringarm, P., \& Singseewo, A. 2009. Effects of learninrg environmental education using the 5Es-learning cycle approach with metacognitive moves and teacher's handbook approaches on learning achievement, integrated science proses skills and critical thinking of high school (grade 9) students. Pakistan Journal of Social Sciences. 6(5): 287-291.

Arif, S. 2001. Pemerdayaan Pembelajaran IPA dalam Upaya Menumbuhkembangkan Sikap Positif terhadap Lingkungan. Jurnal Pendidikan dan Kebudayaan, Nomor 032, Tahun ke-7, November 2001.

Arikunto, Suharsimi. 2006. Prosedur Penelitian Suatu Pendekatan Praktek. Edisi Revisi VI. Jakarta : Rineka Cipta.

BSNP. 2006. Panduan Penyusunan Kurikulum Tingkat Satuan Pendidikan Dasar dan Menengah. Depdiknas.

Budprom, W., Suksringam, P., \& Singsriwo, A. 2010. Effects of learninrg environmental education using the 5E-learning cycle with multiple intelligences and teacher's handbook approaches on learning achievement, basic science proses skills and critical thinking of grade 9 students. Pakistan Journal of Social Sciences. 7(3): 200204.

Chowdhury, M. S., \& College, M. 2006. Human behavior in the context of training: An overview of the role of learning theories as applied to training and development. Journal of Knowledge Management Practice. 7(2). 1-7.

Costu, B., Ayas, A., \& Niaz, M. 2010. Promoting conceptual change in first year students understanding of evaporation. Journal of Chemistry Education Research and Practice. 11: 5-6.

Fishbein, Martin dan Icek Ajzen. 1975. Belief, Attitude, Intention, and Behavior : an Introduction to Theory and Research. London Addison. Wesley Published Company.

Fosnot.1996. Enquiring Teacherrs. Enquiring Learners. A Constructivist Approach 
for Teaching. New York: Columbia University.

Haryanto, dkk (2016) Efektivitas Model Learning Cycle 7E Meningkatkan Aktivitas Belajar Dan Karakter Jujur Dalam Pembelajaran Akuntansi. Jurnal Online Mahasiswa UNRI, 3(2).

Kitjinda, O. N., Suksringarm, P., \& Singseewo, A. 2009. Effects of environmental education learning by using the 7E-learning cycle with multiple intellegences and teacher's handbook approaches on learning achievement, critical thinking and integrated science proses skills of highh school (grade 10) students. Pakistan Journal of Social Sciences. 6(5): 292-296.

Kocakulah, M. S., \& Kural, M. 2010. Investigation of conceptual change about double-slit interference in secondary school physics. Internasional Journal of Environmental \& Science Education. 5(10): 435-460.

Lie, Anita. 2007. Cooperative Learning. Jakarta : Penerbit PT Grasindo.

Lunenburg, F. C. 2011. Critical thinking and constructivism techniques for improving student achievement. National Forum of Teacher Education Journal. 21(3): 1-9.

Maulina, Lingga Asni, dkk. 2018. Penerapan Model Learning Cycle 7E Untuk Meningkatkan Aktivitas dan Hasil Belajar Siswa. Jurnal Edukasi, 5 (1).

Muslimin, dkk.2000. Pembelajaran Kooperatif. Surabaya: Unesa University Press.

Nurkancana, I W dan Sunartana. 1992. Evaluasi Hasil Belajar. Surabaya : Usaha Nasional.

Polyiem, T., Nuangchalerm, P., \& Wongeharta, P. 2011. Learning achievement, science process skill, and moral reasoning of ninth grade students learned by $7 \mathrm{e}$ learning cycle and socioscientific issue-based learning. Australian Journal of Basic and Applied Sciences. 5(10): 257-564.
Puskur. 2006. KTSP SMP/MTs Mata Pelajaran IPA. Depdiknas.

Rookhached, C., Suksringarm, P., \& Singseewo, A. 2010. The Comparation of science education record in life and environment subject using the 7 steps learning cycle using multiple intelligences and metacognitive techniques with a teacher handbook learning that affecting to learning achievement, critical thinking and environmental preservation behavior of secondary school students, year 2 who have a different learning results. Pakistan Journal of Social Sciences. 7 (4): 297-291.

Sadia, I.W. 1996. Pengembangan Model Belajar Konstruktivis Dalam Pembelajaran IPA di SMP. Disertasi PPS UPI Bandung: Tidak Diterbitkan.

Santyasa, I W. 2008a. Asesmen kinerja, fortofolio, dan kriteria penilaian. Makalah. Disajikan dalam pelatihan tentang pembelajaran dan assesmen inovatif bagi guru-guru sekolah menengah di Kecamaan Nusa Penida, tanggal 22, 23, dan 24 Agustus 2008 di Nusa Penida.

Santyasa, I W. 2008b. Pembelajaran berbasis masalah dan pembelajaran kooperatif. Makalah. Disajikan dalam pelatihan tentang pembelajaran dan assesmen inovatif bagi guru-guru sekolah menengah di Kecamaan Nusa Penida, tanggal 22, 23, dan 24 Agustus 2008 di Nusa Penida.

Setiawan, Didang. 2004. Konstruktivisme dalam Pembelajaran. Buletin Pusat Perbukuan Depdiknas Vol. 10 Tahun 2004.

Slavin, R. E. 2009. Psikologi pendidikan: Teori dan prakteknya. Terjemahan: educational psycology: Theoy and practice, oleh Marianto Samosir. Jakarta: Indeks.

Slavin, Robert E. 2005. Cooperative Learning. Theory, Research, and Practice: Second Edition. Boston: Allyn and Bacon. 
Soejono, 1998. Banyaknya daur ulang dalam penelitian tindakan kelas. Aneka Widya. Edisi khusus th XXX. September.

Sornsakda, S., Sukaringarm, P., \& Singseewo, A. 2009. Effects of learning environmental education using the $7 \mathrm{E}$ learning cycle with metacognitive techniques and teacher's handbook approaches on learning achievement, integrated science proses skills and critical thinking of mathayomsuksa 5 students with different learning achievement. Pakistan Journal of Social Sciences. 6(5): 297-303.

Sumiyati, Yeti, dkk. 2016. Penerapan Model Learning Cycle 7E Untuk Meningkatkan Hasil Belajar Siswa Pada Materi Proses Daur Air. Jurnal Pena Ilmiah, 1 (1).
Susilawati, Komang Adyana, dkk. 2014. Pengaruh Model Siklus Belajar 7E Terhadap Pemahaman Konsep Biologi Dan Sikap Ilmiah Siswa. e-Journal Program Pascasarjana Universitas Pendidikan Ganesha Program Studi IPA, 4(1).

Susilawati, Maknun, J., \& Rusdiana, D. 2010. Penerapan Model Siklus Belajar Hipotetikal Deduktif 7e Untuk Meningkatkan Keterampilan Proses Sains Siswa SMA pada Konsep Pembiasan Cahaya. Prosiding Seminar Nasional Fisika 2010 ISBN: 978-979-98010-6-7.

Suzuk, E., Corlu, M. A., \& Gurel, C. 2011. Students' perceptions of learning effiency of introductory physics course. Eurasian Journal Physics and Chemistry Education. 65-71. 